\title{
An Inquiry into the Relationship between Employee Development and Organization Satisfaction in the Federal Sector
}

\author{
Yongjin $\mathrm{Sa}^{1}$, Cynthia Burns ${ }^{1} \&$ Conrad Sullivan ${ }^{1}$ \\ ${ }^{1}$ School of Public and International Affairs, University of Baltimore, Baltimore, MD, USA \\ Correspondence: Yongjin Sa, School of Public and International Affairs, University of Baltimore, Baltimore, MD, \\ USA. E-mail: yongjinsa@gmail.com
}

\author{
Received: January 13, 2014 Accepted: April 28, 2014 Online Published: May 26, 2014 \\ doi:10.5539/ass.v10n12p119 URL: http://dx.doi.org/10.5539/ass.v10n12p119
}

\begin{abstract}
This study explores the relationship between employee development and their organization satisfaction, in an effort to more fully understand how employee development contributes to an agency's success. In order to examine the empirical relationship, this study uses the 2004, 2006, and 2008 Federal Human Capital Survey (FHCS) data. Based on the empirical results from the ordinary least squares regression, this study finds that all dimensions of employee development have positive and significant relationships with an employee's perceived organization satisfaction. One of the interesting findings from the regression analysis is that the positive effect of having electronic access to learning and training programs on an employee's perceived organization satisfaction is the lowest among those eight dimensions of employee development. Conversely, the positive effect of having a real opportunity to improve an employee's skills on an employee's perceived organization satisfaction is higher than effects of any other dimensions of employee development.
\end{abstract}

Keywords: employee development, organization satisfaction, federal agencies

\section{Introduction}

The federal government employs nearly two million people (U.S. Merit Systems Protection Board, 2011). Each of these employees requires various levels of training and development in order to successfully perform their assigned tasks, which at $\$ 1$ billion is a significant cost to taxpayers (U.S. Merit Systems Protection Board, 1995). The expectation is that the investment in federal employees is necessary to successfully provide a level of public goods and services that are expected from our federal workforce. This study explores the relationship between employee development and their organization satisfaction, in an effort to more fully understand how employee development contributes to an agency's success.

\section{Employee Development}

According to Riccucci \& Naff (2008), employee development is the "process of advancing or progressing within an organization while acquiring skill and experience" (p. 340); it allows the organization to accomplish its mission while allowing employees to satisfy their need for professional and personal growth. Employee development includes a spectrum of opportunities that include such activities as technical training, formal education, job enrichment, and developmental assignments.

Technical training is provided to instruct employees on the skills required to perform an assigned task or specific job function. This type of employee development is mostly considered a required cost of doing business. Bedwell \& Salas (2010) report a planning figure for training costs as $1-3 \%$ of payroll costs. Development costs for companies in 2008 exceeded $\$ 130$ billion. In 1991, the federal government alone spent $\$ 1.4$ billion dollars on employee training (U.S. Merit Systems Protection Board, 1995).

Employers may also provide formal educational opportunities to employees. This type of benefit is often at the employer's discretion and may involve paying for tuition, fees and required materials (books, computers, and software). Another type of development is job enrichment, a method in which an employee remains in the current assignment but the scope of the assignment is broadened. Developmental assignments involve horizontal movement where the employee receives the same pay but is given a different position within the organization. The horizontal movement broadens employees' knowledge of the organization and provides the opportunity to develop additional skills such as supervisory or another technical competency. 
Employers and employees pursue occupational development to provide needed skills to become more proficient in their current positions, to develop potential for assignments of greater skill, and to keep employees engaged (Riccucci \& Naff, 2008). For example, federal employees that are interested in career progression to the executive level must acquire the following executive core qualifications (ECQ); 1) Leading Change, 2) Leading People, 3) Results Driven, 4) Business Acumen and 5) Building Coalition. Leading Change is described as a "core qualification [that] involves the ability to bring about strategic change, both within and outside the organization" (Office of Personnel Management, 2013). Leading People is described as the "core qualification [that] involves the ability to lead people toward meeting the organization's vision, mission, and goals" (Office of Personnel Management, 2013). Results Driven is the "core qualification [that] involves the ability to meet organizational goals and customer expectations" (Office of Personnel Management, 2013). Business Acumen is the "core qualification [that] involves the ability to manage human, financial, and information resources strategically" (Office of Personnel Management, 2013). Finally, Building Coalitions is the "core qualification [that] involves the ability to build coalitions internally and with other Federal agencies, State and local governments, nonprofit and private sector organizations, foreign governments, or international organizations to achieve common goals" (Office of Personnel Management, 2013). The ECQs are broadly defined capabilities required by the Office of Personnel Management for every senior executive and may be complemented by a set of technical qualifications unique to that agency's mission (Office of Personnel Management, 2013). Federal employees aspiring to become a senior executive must develop these five qualifications through employee development; their inability to gain these competencies erodes their perception of fairness in the promotional system (U.S. Merit Systems Protection Board, 2009) and may affect their overall satisfaction within the organization.

As an employer, it is essential to understand morale and individual motivations in order to retain productive employees. Federal managers, unlike their private industry counterparts, are particularly constrained in many aspects of personnel management. For most federal sector employees, pay structures and promotional ladders are defined by legislation and OPM regulations. Due to the centralized nature of federal employees' management, agencies and agency managers must seek creative means to satisfy employee motivation and increase morale. Employee development is a way to satisfy organization and employee needs that is within the control of local authority. While OPM oversees policies and programs, implementation of employee development has been decentralized; individual agencies establish requirements tailored for their environment, and are permitted to allocate funds for employee training and development (U.S. Merit Systems Protection Board, 1995).

Training for federal employees became institutionalized by the Government Employees Training Act in 1958 (U.S. Merit Systems Protection Board, 1995). This act was amended in 1993 to expand the scope of acceptable training from that which affects a single job to that which affects the agency mission. Due to the expanded allowance, federal employee training now includes a myriad of different opportunities, some of which are mandated, such as new employee orientation, skills and literacy training, academic degree training, and training for special emphasis programs. It is important that employee development opportunities are offered fairly and equitably (U.S. Merit Systems Protection Board, 2011) to all employees within the agency. Failure to allocate training fairly to organizational members, and to do so in a methodology of selection transparency, could have a negative impact of causing employee dissatisfaction. In the 2005 Merit Principles Survey (MPS), a majority of federal employees responded that training is adequate; however, nearly half of the surveyed employees had a desire for more training (U.S. Merit Systems Protection Board, 2007). Furthermore, employee development was found to be underutilized as a means of engaging federal employees by the US MSPB (2009), with the 2007 MPS results indicating that barely fifty percent of employees responded that they had "real opportunities" (U.S. Merit Systems Protection Board 2009, iv) for improvement. This response should be a trigger for action by federal managers that employee attitudes are influenced by their perception of organizational support for occupational development and education (Kraimer, Seibert, Wayne, Liden, \& Bravo, 2011).

\section{Organization Satisfaction}

As with employee development, employee motivation is a key factor in an employee's satisfaction with the organization. Rainey describes that "content theories" and "process theories" are two major "theories of work motivation" (Rainey, 2009, p. 274). Both types of theories seek to explain what motivates employees; content theories use the perspective of what "needs, motives, and incentives" affect motivation, and process theories focus on the "psychological and behavioral processes" (Rainey, 2009, p. 274). These descriptors are similar to constructs that describe extrinsic and intrinsic motivations. Like content theories, extrinsic motivation is derived from rewards given by others "such as salaries" while intrinsic motivation is derived from oneself such as "enjoyment of the work itself and a sense of growth, achievement, and fulfillment" (Rainey, 2009, p. 277).

The theory of public service motivation (PSM) is specifically relevant to organization satisfaction in the federal 
sector. Employees with high PSM are less likely to consider leaving the government (Naff \& Crum, 1999). PSM theories seek to describe and explain the unique aspect of people who focus their employment in the public sector where extrinsic rewards are constrained. Federal employment offers the opportunity to satisfy instrumental, norm-based, and affective motivations (Rainey, 2009, p. 267). Employees with instrumental motivations are concerned with a particular program, whereas employees with norm-based motivations are concerned with interests of large scale public value such as patriotism and fairness (Rainey, 2009; Naff \& Crum, 1999). Employees with affective motivation seek work which fulfills a psychological "social importance" need... a "devotion to social equity" (Rainey, 2009, p. 267). These PSMs are found in Samaritans, communitarians, patriots and humanitarians. PSM is important to understanding organization satisfaction due to its focus on the greater good rather than on individual benefits. Public employees may or may not be satisfied with their job, their pay or their agencies investment in them, yet they are still motivated by the agency mission. In fact, in the 2005 MSP survey, ninety-five percent of employees "believe their agency's mission is important" (U.S. Merit Systems Protection Board, 2007).

Organizational commitment, the reason an employee remains with an organization, is an additional factor that contributes to organization satisfaction (Meyer \& Allen, 1991). Lee \& Bruvold (2003) describe organizational commitment as affective or continuance. In addition to affective and continuance commitment, Meyer \& Allen (1991) also include a normative component to commitment. In affective commitment employees are emotionally attached to the organization while in continuance commitment the employee is tied to interests outside of the organization such as retirement benefits or personal responsibilities. Employees with normative commitment feel an obligation to remain. Meyer \& Allen (1991) refer to these motivations as "a desire, a need, and/or an obligation to maintain membership in the organization" (p. 62). According to Peterson (2004), organizational rewards lead to perceived organizational support that further leads to affective organizational commitment, which suggests that employee development is an award that can be linked to commitment. Meyer \& Allen (1991) also introduce research that links commitment to a positive attitude toward the organization. Conversely, a normative commitment may be associated with negative attitudes due to the requirement to fulfill an obligation (as incurred from employee development costs).

Employee motivation, public service motivation, and organizational commitment, are three facets of organization satisfaction. Clearly there are a myriad of additional motivators such as salary, benefits, flexible work schedules and others. Federal government employees, however, are different than private sector employees (Naff \& Crum, 1999). An employee's satisfaction with his or her organization may be influenced by constraints on monetary rewards as well as the motivations aligned with creating public value. While these contributors to employees' organization satisfaction are important, this study seeks to isolate the relationship between employee development and its role and impact on organization satisfaction.

\section{Previous Research}

Previous research has explored the relationship between employee development and organization satisfaction. Employee development in the broadest sense incorporates training to acquire necessary skills and competence for the current job as well as satisfying the longer term goals of career development. Based upon an employee survey, the (U.S. Merit Systems Protection Board, 2011) found "greater organizational support" when federal employees' training opportunities are not constrained.

In a study on organizational turnovers, Peterson (2004) concluded that employee development is a consideration of employees when deciding whether to continue within the organization or depart. An organization's demonstrated interest in employee growth is considered supportive of employee needs. When employee development is valued by both the organization and the employee, then organizational commitment will likely be present. Costen \& Salazar (2011) conducted research on the relationship between employee development and satisfaction. They defined satisfaction as a combination of job satisfaction, loyalty, and the intent to stay. In a survey of 641 employees in the lodging industry, the study resulted in a positive and significant relationship between the opportunities to develop new skills and opportunities for advancement and overall satisfaction. The perceived support for development was studied by Kraimer et al. (2011). In this two-part study of successful businesses in insurance and manufacturing, the authors concluded that investment in employee development yields more returns if employees perceive that the organization supports their development and career. Likewise, participation in development has a positive relationship with the "perception of organizational support for development" (Kraimer et al., 2011, p. 485). The relationship between employee development and perceived organizational support (POS) is as important as the relationship between POS and turnover (Allen, Shore, \& Griffieth, 2003). 
Meyer \& Allen (1991) developed a model to portray antecedents to commitment that include employee development components such as job-related characteristics, work experience, and investments (both as a condition of employment and during employment). Rhoades, Eisenberger, \& Armeli (2001) conducted three separate studies of the relationship between work experiences and perceived organizational support and affective commitment. They concluded that employee perception of support from the organization, in terms of work experience (support by the supervisor, rewards, fairness in resource allocation), influences employee affective commitment.

The relationship between socialization, demographics, job satisfaction, and organizational commitment, was the focus of a study conducted by Taormina (1999) of full-time employees in Hong Kong. The distinction between job and organization satisfaction is worth noting, however, because discussions of commitment are typically at the organizational level. This indirect association contributes to the understanding of the relationship between employee development and organization satisfaction. Taormina (1999) concluded that employees who were offered advancement opportunities were more satisfied [with work and pay] and more likely to feel committed to the organization. In addition to advancement opportunities, better training led to higher willingness of employees to continue with the organization, and was the most influential predictor of commitment.

\section{Research Question and Hypothesis}

The literature indicates that there is a positive relationship between employee development and organization satisfaction. This avenue of research is particularly relevant in the federal sector where employee salary and bonus compensation is highly structured and payroll budgets may be constrained by political activity. Employee development does provide an alternative to salary increases and promotions as incentives; therefore, a committed investment to employee development may lead to increases in organization satisfaction. In particular, investment in employee development may increase employee commitment and a decreased turnover rate; these efforts to prevent dissatisfaction could result in a reduction of withdrawals (Hom \& Kinicki, 2001). Considering the importance of effective human resource management to a quality workforce, every avenue to recruit, motivate, and maintain a strong workforce, should be explored.

Hypothesis: A successful employee development structure improves an employee's organization satisfaction.

Research Question: Is there a relationship between employee development and organization satisfaction in the public sector?

\section{Data Source and Sample}

In order to examine the empirical relationship between employee development and organization satisfaction in the federal government, this study uses the Federal Human Capital Survey (FHCS) data. The surveys have been collected and published by the U.S. Office of Personnel Management (OPM) on a bi-annual basis since 2002. The FHCS is based on federal government employees and is administrated to full-time and permanent employees of major agencies represented in the President's Management Council (PMC), and also includes other small and independent agencies. Appendix A1 specifically shows a list of agencies that participated in the 2004, 2006, and 2008 surveys, as well as the total number of survey respondents in each of the federal agencies. All of the independent variables (i.e., employee development), the dependent variable (i.e., organization satisfaction), and several control variables (e.g., sex, age, organizational tenure years, supervisory level, and working location) are constructed using the FHCS questionnaire. The unit of analysis used in this study is individual government employees.

This study uses combined data from the 2004, 2006, and 2008 surveys in order to make causal inferences based on the observed relationships between employee development and organization satisfaction. In doing so, this study has a distinct point from previous studies which uses cross-sectional data for one specific year of the FHCS (e.g., Bertelli, 2007; Fernandez, 2008; Lee \& Whitford, 2008; Pitts, 2009; Choi \& Rainey, 2010; Choi, 2009; Rubin, 2009). Of the more than 276,000 employees receiving the 2004 FHCS, 147,914 employees completed the survey for a response rate of 54 percent. Also, of the 390,657 employees receiving the 2006 FHCS, 221,479 employees completed the survey for a response rate of 57 percent. Finally, of the 417,128 employees receiving the 2008 FHCS, 212,223 employees completed the survey for a response rate of 51 percent. The final sample of this study does not include some cases which include missing values for specific survey questions. As a result, responses for the surveys of 431,763 employees were finally chosen and used for this research and its analysis as shown in Table 1 and 2. 


\section{Variables and Operationalization}

\subsection{Dependent Variable}

The dependent variable of this study is the employee's perceived organization satisfaction. Organization satisfaction is constructed from two survey questions, "I recommend my organization as a good place to work" (q8) and "Considering everything, how satisfied are you with your organization?" (q61). The responses were measured using a Likert-type five-point scale from "strongly disagree" (1) to "strongly agree" (5) for q8 as well as "very dissatisfied" (1) to "very satisfied" (5) for q61. This study uses average values for employees" responses for those two questions to operationalize its dependent variable of organizational satisfaction. The mean value for the dependent variable is 3.591, as shown in Table 1.

\subsection{Independent Variables}

The independent variable of this research is employee development. To operationalize it, this study uses the following eight survey questions: (1) "I am given a real opportunity to improve my skills in my organization" (q2); (2) "The workforce has the job-relevant knowledge and skills necessary to accomplish organizational goals" (q11); (3) "Supervisors/team leaders in my work unit provide employees with the opportunities to demonstrate their leadership skills" (q13); (4) "The skill level in my work unit has improved in the past year" (q15); (5) "Supervisors/team leaders in my work unit support employee development" (q47); (6) "Employees have electronic access to learning and training programs readily available at their desk" (q48); (7) "My training needs are assessed" (q49); and (8) "How satisfied are you with the training you receive for your present job" (q58). Those responses were measured using a Likert-type five-point scale from "strongly disagree" (1) to "strongly agree" (5) for q2,11,13,15, 47, 48, and 49 as well as "very dissatisfied" (1) to "very satisfied" (5) for q58. The mean values for each of the independent variable are identified in Table 1.

\subsection{Control Variables}

This research model also includes several control variables such as sex, age, working location, organizational tenure years, and supervisory level in its regression model. First of all, there are two dichotomous variables such as sex, coded 0 for female employees and 1 for male employees, and working location measured by employees' responses for "Where do you work", coded 0 for the headquarters and 1 for the field. In addition, age group is measured by five scales where $1=$ under $29,2=30-39,3=40-49,4=50-59$, and $5=$ over 60 years. The organizational tenure year is measured by responses for "How long have you been with your current agency?" by using six scales where $1=$ less than 1 year, $2=1-3$ years, $3=4-5$ years, $4=6-10$ years, $5=11-20$ years, and $6=$ over 20 years. The employee supervisory level is measured using five scales where $1=$ non-supervisors, $2=$ team leaders, $3=$ supervisors, $4=$ managers, and $5=$ executives.

Table 1. Descriptive statistics

\begin{tabular}{|c|c|c|c|}
\hline Variable & Mean & $\begin{array}{l}\text { Standard } \\
\text { Deviation }\end{array}$ & $\mathbf{N}$ \\
\hline Organizational Satisfaction & 3.591 & 1.040 & 581616 \\
\hline I am given a real opportunity to improve my skills in my organization. & 3.647 & 1.091 & 581616 \\
\hline $\begin{array}{l}\text { The workforce has the job-relevant knowledge and skills necessary to accomplish } \\
\text { organizational goals. }\end{array}$ & 3.802 & 0.892 & 581616 \\
\hline $\begin{array}{l}\text { Supervisors/team leaders in my work unit provide employees with the opportunities to } \\
\text { demonstrate their leadership skills. }\end{array}$ & 3.634 & 1.080 & 581616 \\
\hline The skill level in my work unit has improved in the past year. & 3.456 & 1.041 & 581616 \\
\hline Supervisors/team leaders in my work unit support employee development. & 3.699 & 1.028 & 581616 \\
\hline $\begin{array}{l}\text { Employees have electronic access to learning and training programs readily available at } \\
\text { their desk. }\end{array}$ & 3.902 & 0.920 & 581616 \\
\hline My training needs are assessed. & 3.321 & 1.076 & 581616 \\
\hline How satisfied are you with the training you receive for your present job? & 3.430 & 1.063 & 581616 \\
\hline $\operatorname{Sex}(0=$ female; $1=$ male $)$ & 0.459 & 0.410 & 431763 \\
\hline Age $(1-5)$ & 3.412 & 0.880 & 581616 \\
\hline Organizational Tenure Years (1-6) & 4.907 & 0.940 & 581616 \\
\hline Supervisory Level (1-5) & 1.934 & 1.043 & 581616 \\
\hline Working Location ( $0=$ headquarter; $1=$ field office $)$ & 0.630 & 0.440 & 581616 \\
\hline
\end{tabular}




\section{Methodology and Model Specification}

As noted above, the dependent variable of employee's perceived organizational satisfaction is measured on a five-point Likert-type scale. From a methodological point of view, the ordinal variable does not meet the fundamental assumptions of the ordinary least squares (OLS) regression. Therefore, the analysis for determinants of an ordinal variable by using OLS regression is likely to have biased coefficients and misleading links between dependent and independent variables, compared to true attributes of the population.

However, in order to explore the relationship between employee development and organizational satisfaction in federal agencies, this study conducts OLS regression rather than ordered probit or logit analysis based on the following two grounds. First, as described earlier, since two survey questions (q8 and q61) are combined into one variable of organizational satisfaction by using their average scores, this study considers the organization satisfaction as a continuous dependent variable rather than a discrete one. Second, in case of large-N data analysis, the violations of an ordinal dependent variable are less likely to influence the OLS regression results. As a result, the difference for statistical results between the OLS and probit analyses is not significant (Pitts, 2009). Finally, this research also tests and confirms that there is no methodological problem or violation of the assumptions of OLS regression in the model (e.g., outliers, heteroscedasticity, multicollinearity, and nonlinear relationships between dependent and independent variables).

\section{Model Estimations and Findings}

As shown in Table 1, an employee's perception on the extent to which they have electronic access to learning and training programs, readily available at their desk, has the highest mean value of 3.902 among independent variables of employee development. On the contrary, an employee's perception that his/her training needs are assessed holds the lowest level of response (i.e., its mean value is 3.321). All of the independent and dependent variables included in the model have mean values which are greater than the mid-point of measurement scale (i.e., neither agree nor disagree; neither satisfied nor dissatisfied).

The empirical findings presented in Table 2 demonstrate that all dimensions of employee development have positive and significant relationships with an employee's perceived organizational satisfaction at the 0.01 significance level. In other words, this research confirms that federal employees who have a higher level of positive perception on employee development (e.g., opportunities to improve job skills, having job-relevant knowledge, supervisors/team leaders' support for employees development and leadership skills, having available electronic access to leaning programs, and fulfillment of employees' training needs) in their agencies are likely to respond to a higher level of their perceived organization satisfaction based on its empirical results. The empirical findings are consistent with previous studies which discuss that investment in employee development leads to increases in employees' organization satisfaction and employee commitment (e.g., Hom \& Kinicki, 2001; Costen \& Salazar, 2011; Taormina, 1999).

One of the interesting findings from the regression analysis is that the positive effect of having electronic access to learning and training programs on an employee's perceived organization satisfaction is the lowest $(0.024$, $\mathrm{p}<0.01)$ among those eight dimensions of employee development, even though an employee's perception on the extent to which he or she has electronic access to learning and training programs readily available at their desk has the highest mean value of 3.902. Conversely, the positive effect of having a real opportunity to improve an employee's skills on an employee's perceived organizational satisfaction is higher $(0.242, p<0.01)$ than effects of any other dimensions of employee development.

With regard to control variables, male employees and employees who work in field offices have more positive perceptions on organizational satisfaction than do female employees, and employees who work in headquarters. In addition, as an employee's age or supervisory level increases, an employee's perceived organizational satisfaction is also likely to increase. Finally, employees who have more years of working in their agencies are likely to report to a lower level of organization satisfaction.

\section{Discussion}

The search for employment is a daunting task, to say the least, filled with various feelings of emotion. As one searches for employment, they seek out many attributes of potential employers to fulfill a variety of personal needs as identified by Abraham Maslow (Rainey, 2009, p. 275). Somewhere within their hierarchy of needs is the satisfaction of education and training, which is a need that could begin very low in one's hierarchy as they strive towards self-actualization. Employers in the private, public, and non-profit sectors, realize this fact and formulate various educational and training programs and benefits to entice potential employees to choose their agency or organization for employment. Organizations tend to seek the best and brightest, and offer various 
educational and training packages to assist their employees to become better and brighter. As a result, this study was instrumental in determining the actual feelings of federal employees in regards to organization satisfaction in terms of the education, training and other opportunities that they perceive to receive.

The literature review of this study documented the fact that the federal government is a massive organization that spends a tremendous amount of money each year on education and training. Several reasons for this expenditure were cited, one of which is to provide technical training for employees to better understand their roles and responsibilities, another is to provide job enrichment and a third is to provide developmental assignments for continued growth and improvement. These factors are illustrated by Barnard as biological factors to improve the cooperative systems within an organization, as he states "they take the forms chiefly of education and training and the specializations of opportunity to develop personal skills" (Barnard, 1938, p. 55).

Also cited was the use of formal education in this same set of expenditures. Formal education, described as education received in a collegiate setting, also assists with improving employees with satisfying the cooperative system by being better at their jobs, but also allows federal employers to satisfy some of the inducements described by Barnard. Educational benefits are another form of both material and "personal non-material opportunities" that provide "opportunities for distinction, prestige, personal power and the attainment of dominating position" (Barnard, 1938, p. 145). These benefits not only allow employees to receive a prestigious college education at the expense of the federal government, but also allow them to attain higher positions within the organization that require a higher education. These inducements, with a high importance as described by Barnard, is seemingly what drives the federal government to provide educational and training programs to assist employees in developing the executive core qualifications for advancement that were briefly described.

This study examined the perceptions of federal employees, using the FHCS data from 2004, 2006 and 2008, with a hypothesis that a successful employee development structure improves an employee's organization satisfaction. Considering that Barnard, even in 1938 when he completed Functions of the Executive, considered education and training as being such a critical aspect of ensuring a cooperative system, and the fact that education and training is a major incentive offered today, it seemed obvious that the hypothesis would be supported by the perceptions of federal employees. The research question, asking whether there is a relationship between employee development and organization satisfaction, is reliable in confirming the hypothesis. The data source provides a sample of subjects from all facets of federal service, as they are representative of a myriad of different professions and fields of occupation that make up nearly the entire federal workforce. The study is surely generalizable of the federal workforce, and would thus seem to be generalizable to public service in general. One suggestion for future study, and a possible weakness in this study, is the fact that a sampling of the perception of state and local employees also be studied to determine if the perceptions are the same or different among various levels of government.

The two survey questions selected tend to weigh an employee's overall satisfaction level of their organization, while the independent variable questions were used to determine the impact and/or causation of those items on satisfaction. The study did provide some expected results, while also equally providing a few interesting results. First is the fact that the hypothesis was supported by the study, in that a successful employee development structure does improve an employee's organization satisfaction. The hypothesis, based on literature review and theories of founding members of public administration, was expected to be accurate, but needed to be confirmed. However, the study does illustrate some areas for improvement among managers within the public sector.

First is the fact that employees on average agreed that they had training programs readily available at their desks; however, they were more neutral that their needs were being assessed. This finding would illustrate that more emphasis should be placed on assessing the training needs of employees. This finding might suggest that training programs are being provided, but that employees are not included in the selection process of what is needed or desired. A qualitative study would need to be conducted to determine why employees feel their needs are not being assessed, to the same level that programs are being provided.

Second is the fact that employees on average agreed that supervisors and team leaders support employee development, and that they are given real opportunities to improve their skills, but they are closer to neutral with the satisfaction of the training they are actually receiving. This would tend to suggest that organizations are possibly offering what is perceived to be the wrong types of training to provoke higher satisfaction. This finding supports the thought that employees are possibly not given much say in what training they feel is more useful, needed, or desired.

Third, the knowledge and skills of the workforce that is needed to accomplish organizational goals was the second highest mean. Employees obviously felt their workshops were knowledgeable and skillful in meeting 
organizational goals, while at the same time they had a lower perception that the work unit improved in the past year. This finding illustrates the above that even though opportunities are available, employees are possibly not taking full advantage of those opportunities.

The control variables also illustrated some interesting findings. Male employees had a higher positive perception on organizational satisfaction than did female employees, as well as those in the field as compared to those in headquarter positions. Could this be attributed to a lack of educational and training programs for Headquarters personnel and female employees? There does seem to be an opportunity here for employers to study ways to increase the satisfaction levels of both female and headquarter employees, whether that is through the inducement of more training and educational programs, or some other venue. This finding would support the need for future research to determine the causation of higher levels of satisfaction among male and field employees.

\section{Conclusion}

Waldo stated that "part of the general movement for better personnel and better management of personnel, and related to such other activities as academic study of public administration, has been the development of educational or training programs for public employees" (Waldo, 1948, p. 30). Ten years earlier Barnard, as illustrated, preceded those comments with the importance of education and training, not only for the betterment of the organization, but also the satisfaction and morale of employees. Literature review has illustrated both as well, that a comprehensive education and training structure aids public sector agencies to operate more effectively and efficiently, as well as helping them develop better and brighter employees.

The hypothesis was supported from the data that was supplied, even though some questions were left unanswered, while other recommendations were suggested. First, managers seemingly could improve in assessing employee needs in terms of training, and ensure the training that is desired and perceived as needed by the employees is offered. Second, managers may improve by researching what educational and training opportunities could be considered, that is fair to both male and female employees, as well as field and headquarters personnel.

There is a suggestion for future research. First, to be more generalizable among all public sector employees and organizations, a study should be completed that includes other levels of government, such as local and state agencies. Second, a qualitative aspect could also be added to future research to determine exactly what aspects are needed in training and education programs to determine why employees may have opportunities and are supported with those efforts, but are not fully taking advantage of those opportunities. Finally, as stated in the discussion segment, a mixed-methods study should be explored to also determine qualitatively why employees feel their needs are not being assessed to the same level that programs are being provided. Part of this study should also examine why employees are possibly not taking full advantage of training opportunities, when those opportunities are perceived by employees to not only exist, but also be supported by management.

In closing, as stated so accurately by Chester Barnard, "the expansion of cooperation and the development of the individual are mutually dependent realities, and that a due proportion or balance between them is a necessary condition of human welfare" (p. 296). The development of our public employees is significant and critical to their contributions to organizational success. Not only does training and development aid in the workforce of all levels of government perform more effectively and efficiently, but also aids in the satisfaction level that employees have toward their individual agency.

"The Individual is always the basic strategic factor in organization. Regardless of his history or his obligations, he must be induced to cooperate, or there can be no cooperation" (Barnard, 1938, p. 139)

Table 2. Ordinary least squares regression results for organization satisfaction

\begin{tabular}{ll}
\hline & $\begin{array}{l}\text { Organization } \\
\text { Satisfaction }\end{array}$ \\
\hline $\begin{array}{l}\text { Independent Variables } \\
\text { I am given a real opportunity to improve my skills in my organization. }\end{array}$ & $0.242^{* * *(0.001)}$ \\
$\begin{array}{l}\text { The workforce has the job-relevant knowledge and skills necessary to accomplish organizational } \\
\text { goals. }\end{array}$ & $0.199^{* * *}(0.001)$ \\
$\begin{array}{l}\text { Supervisors/team leaders in my work unit provide employees with the opportunities to demonstrate } \\
\text { their leadership skills. }\end{array}$ & $0.155^{* * *(0.001)}$ \\
The skill level in my work unit has improved in the past year. & $0.138^{* * *}(0.001)$ \\
\hline
\end{tabular}




\begin{tabular}{ll}
\hline & $\begin{array}{l}\text { Organization } \\
\text { Satisfaction }\end{array}$ \\
\hline Supervisors/team leaders in my work unit support employee development. & $0.110^{* * *}(0.002)$ \\
Employees have electronic access to learning and training programs readily available at their desk. & $0.024 * * *(0.001)$ \\
My training needs are assessed. & $0.029 * * *(0.001)$ \\
How satisfied are you with the training you receive for your present job? & $0.098^{* * *}(0.001)$ \\
Control Variables & $0.019^{* * *}(0.003)$ \\
Sex $(0=$ female; $1=$ male) & $0.006^{* * *}(0.002)$ \\
Age (1-5) & $-0.012 * * *(0.002)$ \\
Organizational Tenure Years (1-6) & $0.011 * * *(0.001)$ \\
Supervisory Level $(1-5)$ & $0.029 * * *(0.003)$ \\
Working Location $(0=$ headquarter; $1=$ field office $)$ & $-0.029 * * * 0.008)$ \\
Intercept & 0.5528 \\
Adjusted ${ }^{2}$ & 41056.04 \\
F-Statistic & $($ Prob $>\mathrm{F}=.00)$ \\
N of Cases & 431763 \\
\hline
\end{tabular}

*Significant at 0.10 level, **Significant at 0.05 level, ***Significant at 0.01 level

The numbers in parentheses refer to standard errors.

\section{References}

Barnard, C. I. (1938). The Functions of the Executive. Cambridge. Boston, MA: Harvard University Press.

Bedwell, W., \& Salas, E. (2013). Computer-Based Training: Capitalizing on Lessons Learned. International Journal of Training and Development, 14, 239-249. http://dx.doi.org/10.1111/j.1468-2419.2010.00355.x

Bertelli, A. M. (2007). Determinants of Bureaucratic Turnover Intention: Evidence from the Department of the Treasury. Journal of Public Administration Research and Theory, 17(2), 235-258. http://dx.doi.org/10.1093/jopart/mul003

Choi, S. (2009). Diversity in the U.S. Federal Government: Diversity Management and Employee Turnover in Federal Agencies. Journal of Public Administration Research and Theory, 19(3), 603-630. http://dx.doi.org/10.1093/jopart/mun010

Choi, S., \& Rainey, H. G. (2010). Managing Diversity in the U.S. Federal agencies: Effects of Diversity and Diversity Management on Employee Perceptions of Organizational Performance. Public Administration Review, 70(1), 109-121. http://dx.doi.org/10.1111/j.1540-6210.2009.02115.x

Costen, W. M., \& Salazar, J. (2011). The Impact of Training and Development on Employee Job Satisfaction, Loyalty, and Intent to Stay in the Lodging Industry. Journal of Human Resources in Hospitality and Tourism, 10(3), 273-284. http://dx.doi.org/10.1080/15332845.2011.555734

Fernandez, S. (2008). Examining the Effects of Leadership Behavior on Employee Perceptions of Performance and Job Satisfaction. Public Performance and Management Review, 32, $175-205$. http://dx.doi.org/10.2753/PMR1530-9576320201

Hom, P. W., \& Kinicki, A. J. (2001). Toward a Greater Understanding of How Dissatisfaction Drives Employee Turnover. Academy of Management Journal, 44(5), 975-987. http://dx.doi.org/10.2307/3069441

Kraimer, M. L., Seibert, S. E., Wayne, S. J., Liden, R. T., \& Bravo, J. (2011). Antecedents and Outcomes of Organizational Support for Development: The Critical Role of Career Opportunities. Journal of Applied Psychology, 96(3), 485-500. http://dx.doi.org/10.1037/a0021452

Lee, C., \& Bruvold, N. (2003). Creating Value for Employees: Investment in Employee Development. International Journal of Human Resource Management, 14(6), 981-1000. http://dx.doi.org/10.1080/0958519032000106173

Lee, S. Y., \& Whitford, A. B. (2008). Exit, Voice, and Pay: Evidence from the Public Workforce. Journal of Public Administration Research and Theory, 18(4), 647-671. http://dx.doi.org/10.1093/jopart/mum029 
Meyer, J. P., \& Allen, N. J. (1991). A Three Component Conceptualization of Organizational Commitment. Human Resource Management Review, 1, 61-98. http://dx.doi.org/10.1016/1053-4822(91)90011-Z

Naff, K., \& Crum, J. (1999). Working for America: Does Public Service Motivation Make a Difference? Review of Public Personnel Administration, 19(4), 5-16. http://dx.doi.org/10.1177/0734371X9901900402

Office of Personnel Management. (2008). The 2008 Federal Human Capital Survey Final Report. Office of Personnel Management. Retrieved April 10, 2013, from http://www.fedview.opm.gov/2008FILES/2008_ UnweightedDemographicReport.pdf

Office of Personnel Management. (2013). Senior Executive Service. Retrieved April 24, 2013, from $\mathrm{http} / /$ www.opm.gov/policy-data-oversight/senior-executive-service/executive-core-qualifications/

Peterson, S. L. (2004). Toward a Theoretical Model of Employee Turnover: A Human Resource Development Perspective. Human Resource Development Review, 3, 209-227. http://dx.doi.org/10.1177/1534484304267832

Pitts, D. W. (2009). Diversity Management, Job Satisfaction, and Performance: Evidence from U.S. Federal $\begin{array}{lllll}\text { Agencies. } & \text { Public } & \text { Administration }\end{array}$ http://dx.doi.org/10.1111/j.1540-6210.2008.01977.x

Rainey, H. G. (2009). Understanding and Managing Public Organizations. San Francisco, CA: Jossey-Bass.

Rhoades, L., Eisenberger, R., \& Armeli, S. (2001). Affective Commitment to the Organization: The Contribution of Perceived Organizational Support. Journal of Applied Psychology, 86(5), 825-836. http://dx.doi.org/10.1037/0021-9010.86.5.825

Riccucci, N., \& Naff, K. (2008). Personnel management in government: Politics and process. Boca Raton, FL: CRC Press.

Rubin, E. V. (2009). The Role of Procedural Justice in Public Personnel Management: Empirical Eesults from the Department of Defense. Journal of Public Administration Research and Theory, 19(1), 125-143. http://dx.doi.org/10.1093/jopart/mum035

Shore, A. D. (2003). The Role of Perceived Organizational Support and Supportive Human Resource Practices in the Turnover Process. Journal of Management, 29(1), 99-118. http://dx.doi.org/10.1177/014920630302900107

Taormina, R. J. (1999). Predicting Employee Commitment and Satisfaction: The Relative Effects of Socialization and Demographics. International Journal of Human Resource Management, 10(6), 1060-1076. http://dx.doi.org/10.1080/095851999340125

U.S. Merit Systems Protection Board. (1995). A Report to the President and the Congress of the United States Leadership for Change Human Resource Development in the Federal Government.

U.S. Merit Systems Protection Board. (2007). A Report to the President and the Congress of the United States Accomplishing our Mission Merit Principles Survey.

U.S. Merit Systems Protection Board. (2009). A Report to the President and the Congress of the United States Managing for Engagement-Communication, Connection, and Courage.

U.S. Merit Systems Protection Board. (2011) A Report to the President and the Congress of the United States Making the Right Connections: Targeting the Best Competencies for Training.

Waldo, D. (1948). The administrative state. New York, NY: The Ronald Press Company.

\section{Appendix A}

Appendix A1. List of agencies participated in the 2004, 2006 and 2008 FHCS

\begin{tabular}{llll}
\hline \multirow{2}{*}{ Agency } & \# of Respondents \\
& 2008 & 2006 & 2004 \\
\hline United States Agency for International Development (AID) & 831 & 726 & 803 \\
Broadcasting Board of Governors (BBG) & 556 & 570 & 543 \\
Court Services and Offender Supervision Agency (CSOSA) & 604 & 518 & 554 \\
Department of Homeland Security (DHS) & 9550 & 10373 & 10478 \\
Department of Commerce (DOC) & 3556 & 5204 & 4021 \\
\hline
\end{tabular}




\begin{tabular}{|c|c|c|c|}
\hline \multirow{2}{*}{ Agency } & \multicolumn{3}{|c|}{ \# of Respondents } \\
\hline & 2008 & 2006 & 2004 \\
\hline Department of Energy (DOE) & 6093 & 7742 & 1485 \\
\hline Department of the Interior (DOI) & 27030 & 25507 & 5187 \\
\hline Department of Justice (DOJ) & 14021 & 10967 & 7701 \\
\hline Department of Labor (DOL) & 4110 & 4538 & 4082 \\
\hline Department of Transportation (DOT) & 6354 & 5453 & 4961 \\
\hline Department of Education (Educ) & 2393 & 2910 & 2408 \\
\hline Equal Employment Opportunity Commission (EEOC) & 1210 & 1173 & 1693 \\
\hline Environmental Protection Agency (EPA) & 6986 & 9115 & 6895 \\
\hline Federal Communications Commission (FCC) & 733 & NA & NA \\
\hline Federal Energy Regulatory Commission (FERC) & 671 & 753 & NA \\
\hline Federal Trade Commission (FTC) & 560 & 459 & 616 \\
\hline General Services Administration (GSA) & 3396 & 3916 & 2869 \\
\hline Department of Health and Human Services (HHS) & 22730 & 25756 & 4653 \\
\hline Department of Housing and Urban Development (HUD) & 3467 & 4075 & 5343 \\
\hline National Archives and Records Administration (NARA) & 1370 & 1442 & 1415 \\
\hline National Aeronautics and Space Administration (NASA) & 4375 & 4734 & 4766 \\
\hline National Credit Union Administration (NCUA) & 588 & 623 & 538 \\
\hline National Labor Relations Board (NLRB) & 803 & 963 & 979 \\
\hline Nuclear Regulatory Commission (NRC) & 2179 & 1692 & 1876 \\
\hline National Science Foundation (NSF) & 583 & 596 & 778 \\
\hline Office of Management and Budget (OMB) & 253 & 250 & 249 \\
\hline Office of Personnel Management (OPM) & 2932 & 3012 & 1539 \\
\hline Pension Benefit Guaranty Corporation (PBGC) & 515 & NA & NA \\
\hline Railroad Retirement Board (RRB) & 570 & 680 & 700 \\
\hline Small Business Administration (SBA) & 1618 & 1447 & 1661 \\
\hline Securities and Exchange Commission (SEC & 1605 & 1905 & 2166 \\
\hline Social Security Administration (SSA) & 5959 & 1317 & 1172 \\
\hline Department of State (State) & 1720 & 1310 & 1272 \\
\hline Department of the Treasury (Treasury) & 8456 & 7042 & 5677 \\
\hline Department of Agriculture (USDA) & 13692 & 13601 & 10404 \\
\hline Department of Veterans Affairs (VA) & 3283 & 3144 & 3344 \\
\hline Small Agencies & 3227 & 4141 & 3679 \\
\hline Department of Defense (DoD) All & 43444 & 50740 & 40196 \\
\hline U.S. Army Corps of Engineers (USACE) & 5035 & 5154 & 6295 \\
\hline Department of the Air Force (Air Force) & 8971 & 10078 & 8696 \\
\hline Department of the Army (Army) & 11658 & 13746 & 8408 \\
\hline Department of the Navy (Navy) & 9578 & 12620 & 9512 \\
\hline U.S. Marine Corps (Marine Corps) & 797 & 912 & 765 \\
\hline Other Department of Defense (DoD) & 7405 & 8230 & 6520 \\
\hline
\end{tabular}

Source: The 2008 Federal Human Capital Survey Final Report, Retrieved from http://www.fedview.opm.gov/2008FILES/2008_UnweightedDemographicReport.pdf

\section{Copyrights}

Copyright for this article is retained by the author(s), with first publication rights granted to the journal.

This is an open-access article distributed under the terms and conditions of the Creative Commons Attribution license (http://creativecommons.org/licenses/by/3.0/). 